\title{
KERENTANAN MENGALAMI KEKERASAN PADA ANAK YANG BERKONFLIK DENGAN HUKUM SELAMA MENJALANI PROSES HUKUM
}

\author{
Nailatin Fauziyah \\ email: nailatinsunanampel@gmail.com \\ Fakultas Psikologi dan Kesehatan \\ Universitas Islam Negeri (UIN) Sunan Ampel Surabaya
}

\begin{abstract}
Abstrak- Penelitian ini bertujuan untuk mengeksplorasi kekerasan yang dialami oleh anak-anak yang berkonflik dengan hukum selama proses hukum, mulai dari tahap penyelidikan ke tahap pengawasan setelah melakukan kriminalitas. Metode yang digunakan adalah studi kasus dan metode penggalian data menggunakan wawancara mendalam dan observasi. Analisis data dalam penelitian ini mengacu pada pendapat Miles dan Huberman, menggunakan tahap pengumpulan data, reduksi data, penyajian data, dan kesimpulan atau verifikasi. Responden terdiri dari 2 anak-anak yang menjalani proses hukum, orang tua dari anak yang berkonflik dengan hukum, dan masyarakat. Hasil penelitian ini menunjukkan bahwa anak-anak yang berkonflik dengan hukum rentan terhadap penyalahgunaan dari tahap penangkapan, penyelidikan, percobaan, dan pasca-vonis. Bentuk-bentuk kekerasan yang dialami oleh anak-anak yang berkonflik dengan hukum termasuk kekerasan fisik, kekerasan psikis, kekerasan verbal, dan penyalahgunaan keuangan. Kekerasan mengalami dampak psikologis, fisiologis, dan sosial pada anak yang berkonflik dengan hukum.
\end{abstract}

Keyword: Anak-anak yang berkonflik dengan hukum, kekerasan, proses hukum

PSIKOISLAMIKA. Jurnal Psikologi Islam (JPI) copyright @ 2016 Pusat Penelitan dan Layanan Psikologi. Volume 13 Nomor 2 Tahun 2016

\section{PENDAHULUAN}

Kekerasan terhadap anak merupakan persoalan yang cukup serius, ditinjau dari peningkatan pengaduan tentang kasus kekerasan anak setiap tahunnya. Data Komisi Nasional Perlindungan Anak (Komnas PA) tahun 2010-2015 menunjukkan bahwa pada 2010 sebanyak 2.046 aduan (42\% kejahatan seksual), 2011 menjadi 2.467 (52\% kejahatan seksual), sementara pada 2012 ada 2.637 ( $62 \%$ kekerasan seksual), meningkat lagi di 2013 menjadi 2.676 (54\% didominasi kejahatan seksual), 2014 sebanyak 2.737 (52\% kekerasan seksual), dan 2015 terjadi peningkatan pengaduan sangat tajam mencapai 2.898
(59,30\% kekerasan seksual) dan sisanya kekerasan lainnya (http://news.liputan6.com/read/2396014/ komnas-pa-2015-kekerasan-anak-tertinggi-selama5-tahun-terakhir 30 sept 2016).

Komisi Perlindungan Anak Indonesia (KPAI) melaporkan bahwa kekerasan pada anak selalu meningkat setiap tahun. Hasil pemantauan KPAI dari 2011 sampai 2014, terjadi peningkatan yang sifnifikan. Tahun 2011 terjadi 2178 kasus kekerasan, 2012 ada 3512 kasus, 2013 ada 4311 kasus, 2014 ada 5066 kasus. $78.3 \%$ anak menjadi pelaku kekerasan dan sebagian besar karena mereka pernah menjadi korban kekerasan sebelumnya atau pernah melihat kekerasan dilakukan kepada 
anak lain dan menirunya (http: //www.kpai.go.id/ berita/kpai-pelaku-kekerasan-terhadap-anak-tiaptahun-meningkat/\#30 sept 2016).

Mengacu pada Undang-undang No.23 Tahun 2002 tentang perlindungan anak, anak didefinisakan sebagai seseorang yang belum berusia 18 (delapan belas) tahun, termasuk anak yang masih dalam kandungan. Kriteria berdasarkan usia tersebut berbeda dengan perspektif psikologi yang menggolongkan usia 12 sampai 18 tahun sebagai masa remaja pertengahan (Monks dkk, 1996), bukan lagi usia anak-anak. Namun, istilah anak yang digunakan dalam penelitian ini mengacu pada konsep anak dalam perspektif hukum atau Undang-undang.

Anak yang berhadapan dengan hukum adalah anak yang berkonflik dengan hukum, anak yang menjadi korban tindak pidana, dan anak yang menjadi saksi tindak pidana. Anak yang berkonflik dengan hukum yang selanjutnya disebut anak adalah anak yang telah berumur 12 (dua belas) tahun, tetapi belum berumur 18 (delapan belas) tahun yang diduga melakukan tindak pidana. Undang-undang No.3 Tahun 1997 menyebutnya sebagai anak nakal, yaitu anak adalah orang yang dalam perkara. Anak Nakal telah mencapai umur 8 (delapan) tahun tetapi belum mencapai umur 18 (delapan belas) tahun dan belum pernah menikah.

Anak yang berhadapan dengan hukum perspektif Konvensi Hak Anak (KHA) dikategorikan sebagai anak dalam situasi khusus (children in need of special protection). UNICEF menyebutnya sebagai Children in aspecially difficult circumstances, karena kebutuhan-kebutuhannya tidak terpenuhi, rentan mengalami kekerasan, berada diluar lingkungan keluarga (berada dilingkup otoritas institusi Negara), membutuhkan proteksi berupa regulasi khusus, dan membutuhkan perlindungan dan keamanan diri. Ilmu Psikologi mengkategorisasikan anak berkonflik hukum $(\mathrm{ABH})$ sebagai Juvenille delinquency, yaitu mengacu kepada suatu rentang perilaku yang luas, mulai dari perilaku yang tidak dapat diterima secara sosial (seperti bertindak berlebihan di sekolah), pelanggaran (seperti melarikan diri dari rumah) hingga tindakan-tindakan kriminal (seperti mencuri) (Santrock, 2002). Secara spesifik disebut dalam DSM-IV sebagai gangguan perilaku (conduct disorder), yaitu suatu pola yang diulang dan menetap dari tingkah laku yang berkaitan dengan hak dasar orang lain atau agresivitas yang tidak sesuai dengan norma-norma masyarakat atau melanggar aturan-aturan.
ABH memiliki kerentanan terhadap tindak kekerasan selama dalam proses hukum. Berdasarkan data penelitian LBH Jakarta tahun 2012, dari 100 responden anak yang menjadi tahanan di Lapas Anak Pria dan Lapas Anak Wanita di Tangerang serta Rutan Pondok Bambu Jakarta Timur, prosentase tidak kekerasan terhadap anak yang tidak didampingi oleh penasehat hukum saat proses penangkapan sebanyak $91 \%$, saat penggeledahan $85 \%$ serta $90 \%$ tidak didampingi dalam proses pemeriksaan di Kepolisidan dan 51 \% ketika proses persidangan. Dari keseluruhan tersebut sebanyak $82 \%$ anak mengalami penyiksaan yang dilakukan saat proses penangkapan, $84 \%$ saat proses BAP dan $48 \%$ saat dilakukan penahanan (http://www. bantuanhukum. or.id/web/penjara-bukan-tempat-untuk-anaklaunching-posko-pengaduan-anak-berhadapandengan-hukum/).

Temuan LBH Jakarta selaras dengan hasil penelitian Listyawati Andayani (2010) tentang Kasus kekerasan anak yang berkonflik dengan hukum menunjukkan bahwa $\mathrm{ABH}$ baik sebagai pelaku maupun korban mengalami kekerasan dimulai pada saat penyidikan di kepolisian hingga di lembaga pemasyarakatan. Kekerasan yang diterima oleh anak yang berkonflik dengan hukum sebagian besar bersifat fisik, tetapi dapat menimbulkan trauma psikis pada anak.

Kekerasan berarti penganiayaan, penyiksaan, atau perlakuan salah. Menurut WHO (dalam Bagong. S, dkk, 2000), kekerasan adalah penggunaan kekuatan fisik dan kekuasaan, ancaman atau tindakan terhadap diri sendiri, perorangan atau sekelompok orang atau masyarakat yang mengakibatkan atau kemungkinan besar mengakibatkan memar/trauma, kematian, kerugian psikologis, kelainan perkembangan atau perampasan hak. Kekerasan pada anak (Child abuse) menurut Barker (dalam Huraerah, 2006) merupakan tindakan melukai beulang-ulang secara fisik dan emosional terhadap anak yang ketergantungan, melalui desakan hasrat, hukuman badan yang tak terkendali, degradasi dan cemoohan permanen atau kekerasan seksual.

Terry E. Lawson (dalam Huraeroh 2006) merumuskan 4 jenis tentang kekerasan terhadap anak yaitu (1) Kekerasan fisik (physical abuse) adalah penyiksaan, pemukulan, dan penganiayaan terhadap anak, dengan atau tanpa menggunakan benda-benda tertentu, yang menimbulkan lukaluka fisik atau kematian pada anak. (2) Kekerasan emosional (emotional abuse) terjadi ketika orang tua/pengasuh dan pelindung anak setelah mengetahui anaknya meminta perhatian, mengabaikan anak itu. 
(3) Kekerasan secara verbal (verbal abuse) Biasanya berupa perilaku verbal dimana pelaku melakukan pola komunikasi yang berisi penghinaan, ataupun kata-kata yang melecehkan anak. (4) Kekerasan seksual (sexual abuse) meliputi pemaksaan hubungan seksual yang dilakukan terhadap orang yang menetap dalam lingkup rumah tangga tersebut (seperti istri, anak dan pekerja rumah tangga).

Bentuk kekerasan terhadap anak yang ditetapkan sebagai tindak pidana telah diatur dalam UU Perlindungan Anak pasal 77 sampai 89. Bentuk kekerasan ini di antaranya diskriminasi, penelantaran, pembiaran, pengangakatan anak yang tidak sesuai pasal 39, kekejaman, kekerasan untuk memaksa persetubuhan, tipu muslihat, perdagangan anak, transplantasi organ, jual beli organ, merekrut anak untuk kepentingan golongan tertentu, eksploitasi ekonomi dan seksual serta melibatkan anak dalam perdagangan narkotika.

Berdasarkan kemungkinan terjadinya kekrasan pada $\mathrm{ABH}$ maka pentingnya penerapan penanganan terhadap $A B H$ yang sesuai dengan standar yang mengacu pada Undang-Undang nomor 23 Tahun 2002 tentang Perlindungan Anak. Standar tersebut meliputi: (a) Perlakuan atas anak secara manusiawi sesuai dengan martabat dan hak-hak anak; (b) penyediaan petugas pendamping khusus bagi anak sejak dini; (c) penyediaan sarana dan prasarana khusus; (d) penjatuhan sanksi yang tepat untuk kepentingan yang terbaik bagi anak; (f) pemberian jaminan untuk mempertahankan hubungan dengan orang tua atau keluarga; (g) perlindungan diri dari pemberitaan identitas melalui media massa dan untuk menghindari labelisasi.

Anak diharapkan dapat tumbuh dan berkembang menjadi remaja yang kreatif, inovatif, mandiri, dan berperilaku sesuai dengan aturan yang ada. Akan tetapi fakta menunjukkan banyak anak-anak yang harus berurusan dengan hukum, baik sebagai korban, saksi, maupun pelaku, dan anak-anak rentan mengalami kekerasan dalam menjalani proses hukum. Oleh karena itu, penelitian ini ingin mengeksplorasi lebih jauh mengenai kekerasan yang dialami oleh anak yang berkonflik dengan hukum dan dampaknya.

\section{METODE}

Untuk mencapai tujuan penelitian ini, maka metode yang digunakan adalah kualitatif dengan tipe studi kasus. Informan dalam penelitian ini meliputi: anak yang berkonflik dengan hukum yang telah selesai menjalani proses hukum karena kasus pengroyokan aparat, orang tua $\mathrm{ABH}$, dan masyarakat. Penentuan informan dengan metode bola salju (snowball) yaitu pengambilan sampel dilakukan secara berantai dengan meminta informasi pada seseorang yang telah diwawancarai atau dihubungi sebelumnya. Informan kunci penelitian ini ada 2 yaitu informan A dan informan B. Informan A di tangkap sehari setelah pengroyokan, ketika ia sedang berada di pasar. Sedangkan informan B seminggu kemudian, ia diminta menyerahkan diri oleh aparat desa dan kemudian diantar ke UPPA oleh aparat desa setempat.

Setting atau konteks penelitian ini adalah peristiwa pengroyokan masyarakat terhadap aparat penegak hukum ketika melakukan razia petasan di salah satu desa yang memproduksi petasan. Peristiwa terjadi di siang hari, di tahun 2014. Ketika itu, datang beberapa mobil aparat penegak hukum untuk melakukan razia petasan di desa. Masyarakat melakukan penolakan dengan melawan aparat. Perlawanannya dengan melempari aparat dengan batu dan membakar mobil aparat tersebut. Masyarakat yang terlibat dalam pengroyokan terdiri dari berbagai usia meliputi dewasa dan anak-anak. Sehari setelah peristiwa tersebut aparat penegak hukum melakukan penangkapan pada para pelaku pengroyokan, baik orang dewasa maupun anakanak.

Teknik pengumpulan data menggunakan wawancara dan observasi. Wawancara yang digunakan dalam penelitian ini adalah wawancara denga tipe open-ended, di mana peneliti dapat bertanya kepada responden kunci tentang fakta-fakta suatu peristiwa di samping opini mereka mengenai peristiwa yang ada. Pada beberapa situasi, peneliti bahkan bisa meminta responden untuk mengetengahkan pendapatnya sendiri terhadap peristiwa tertentu dan bisa menggunakan proposisi tersebut sebagai dasar penelitian selanjutnya (Yin, 2011). Responden kunci ini tidak hanya bisa memberikan keterangan tentang sesuatu kepada peneliti tetapi juga bisa memberikan saran tentang sumber-sumber bukti lain yang mendukung, serta menciptakan akses terhadap sumber yang bersangkutan (Yin, 2011). Observasi langsung, dimana peneliti mengadakan kunjungan lapangan terhadap situs studi kasus. Observasi dapat terbentang mulai pengumpulan data yang formal hingga yang kausal. Yang paling formal, protocol observasi dapat dikembangkan sebagai bagian dari protocol studi kasus, dan peneliti yang bersangkutan bisa diminta untuk mengukur peristiwa tipe perilaku tertentu dalam waktu tertentu (Yin, 
2011). Bukti observasi ini dapat bermanfaat untuk memberikan informasi tambahan tentang topic yang akan diteliti. Sedangkan analisa data dalam penelitian ini mengacu pada pendapat Miles dan Huberman (1992), dengan menggunakan tahapan pengumpulan data, reduksi data, penyajian data, dan penarikan kesimpulan atau verifikasi.

Kualitas penelitian menjadi hal penting sehingga salah satu teknik yang bisa digunakan untuk menilai kualitas sebuah penelitian adalah melihat tingkat kredibilitas penelitian tersebut. Uji kredibilitas penelitian bisa dilakukan melalui menggunaan berbagai sumber data (Yin, 1994). Dasar pemikiran untuk menggunakan berbagai sumber data adalah triangulasi bukti.

\section{HASIL}

\section{Fakta kekerasan Pada Anak Yang Berkonflik Dengan Hukum}

Anak-anak yang berkonflik dengan hukum akan menjalani proses hukum sesuai dengan sistem peradilan anak yang berlaku. Menurut UU No. 11 Tahun 2012, sistem peradilan pidana anak adalah keseluruhan proses penyelesaian perkara anak yang berhadapan dengan hukum, mulai tahap penyidikan sampai dengan tahap pembimbingan setelah menjalani pidana. Adapun tahapan dalam proses peradilan pidana yaitu tahap pra-judikasi (sebelum sidang peradilan) meliputi penyidikan dan penyelidikan, judikasi (selama sidang peradilan) meliputi pemeriksaan dan pembuktian tuntutan jaksa, dan tahap paska-judikasi (setelah sidang peradilan) meliputi pelaksanaan keputusan yang telah ditetapkan dalam persidangan seperti penempatan terpidana dalam lembaga pemasyarakatan (Nashriana, 2001).

Pada tahap-tahap tersebut, anak yang berkonflik dengan hukum rentan mengalami kekerasan.

a) Tahap Pra Judikasi. Tahap prajudikasi merupakan tahap dimana proses penyidikan dan penyelidikan dilakukan. Penyidikan merupakan serangkaian tindakan yang dilakukan oleh pejabat penyidik sesuai dengan cara dalam undang-undang untuk mencari serta mengumpulkan bukti, dan dengan bukti itu membuat atau menjadi terang tindak pidana yang terjadi sekaligus menemukan tersangkanya atau pelaku tindak pidananya (Harahap, 2006).

Ketika menjalani proses penyidikan informan mengalami kekerasan fisik, kekerasan verbal, dan kekerasan psikologis, sebagaimana diceritakan oleh informan A:
"Pada waktu itu saya di bawa ke kantor polisi, disana saya di bentak - bentak, sama di pukul bagian pipi, tangan di piting, terus dipisu pisui, di tendang".

“....yang memberi pertanyaan orang banyak, sekitar 5 orang, di bentak - bentak kalau gak jawab".

"setelah itu dibawa ke PPA, disana ditanya lagi. Kalau gak jawab jujur diserakan, dikembalikan ke atas lagi lo, di pukuli lagi katanya".

Sedangkan pada informan B ketika proses penyidikan di UPPA ia sendirian tidak didampingi pengacara ataupun orang tua. la mengalami kekerasan psikologi ketika berada di UPPA, merasa tertekan dan tidak nyaman karena bentuk pertanyaan dan cara bertanya dari petugas penyidikan, sebagaimana di sampaikan oleh B

“...pertanyaannya mbulet, diputar-putar, saya jadi ndredek".

Pada waktu penangkapan informan A juga mengalami kekerasan fisik sebagaimana di ceritakan oleh informan A.

"Tiba-tiba ada orang nyalamin saya, terus saya ditarik tangan saya, mau saya lepaskan di tarik terus. Saya dimasukkan kedalam mobil, perut saya di jundu rasanya mau muntah, disikut".

b) Tahap Yudikasi (selama sidang peradilan) yaitu meliputi pemeriksaan dan pembuktian tuntutan jaksa. Proses penuntutan hingga putusan hukuman.

Pada waktu proses persidangan informan merasa cemas akan keputusan yang akan dijatuhkan oleh hakim, mereka cemas kalo hukumannya adalah penjara. Hal ini dikarenakan informan memiliki persepsi yang negatif mengenai penjara.

Ketika menjalani proses persidangan, kedua informan mengalami kekerasan finansial dan psikologis, di mana salah satu oknum aparat penegak hukum meminta uang pada informan agar hukumannya ringan. Pada awalnya, masingmasing diminta sebesar 5 juta, namun karena keterbatasan ekonomi maka orang tua informan hanya mampu memberikan 2 juta. Besaran nominal ini berdampak pada putusan. Pada awalnya, tuntutan dari jaksa penuntut umum adalah hukuman 6 bulan tahanan luar, namun karena hanya bisa memberikan uang sebesar 2 juta rupiah maka putusannya menjadi 1 tahun tahanan luar. Sebagaimana disampaikan oleh 
informan

“...waktu di kejaksaan, disuruh nyiapin uang 2 juta dalam 2 jam, awalnya 5 juta tapi di tawar. Jam 11 mintanya, lalu jam 12 gak datang juga uangnya, kalo gak ada uang dibawa ke penjara. Saya dan teman - teman, sama B ini sudah masuk sel bu sekitar 1 jam, Ada uang 2 juta itu, trus dikeluarkan".

c) Tahap pasca yudikasi, yaitu tahap pasca putusan pengadilan.

Hasil putusan pengadilan atas kasus tersebut informan mendapatkan hukuman 1 tahun tahanan luar. Dimana pada setiap hari senin informan diwajibkan mengisi absen di kejaksaan. Pada pelaksanaan proses ini informan cenderung mengalami kekerasan secara verbal dan psikologis. Sebagaimana di ceritakan oleh informan,

“ Bosan, Riwa - riwi, kadang ke sana yang bagian jaga tidak ada, kalo kesiangan dibentakbentak "kene tak lebokno ta?".

\section{Dampak dari kekerasan yang dialami}

Ketika melakukan tindakan pengeroyokan bersama masyarakat, informan tidak memiliki pemikiran bahwa apa yang dilakukannya akan berdampak pada hukum. Mereka hanya mengikuti perilaku orang-orang dewasa disekitarnya. Ketika akhirnya mereka harus menjalani proses hukum atas apa yang dilakukannya dan ternyata selama menjalani proses hukum tersebut mereka banyak mengalami kekerasan, maka secara otomatis apa yang dialami informan tersebut memberikan dampak, baik secara fisik, psikologis, maupun secara sosial.

Hasil dari wawancara dengan informan, adapun dampak yang dirasakan oleh anak-anak yang berkonflik dengan hukum selama mereka menjalani proses hukum adalah sebagai berikut:

1) Dampak Fisik: Badan rasanya sakit semua, memar, mual, kepala sering pusing, tidak bisa tidur, dan nafsu makan berkurang

2) Dampak Psikologis : ketakutan akan hukuman, ketakutan tidak bisa sekolah lagi, tertekan, tidak nyaman, merasa tidak aman, konsentrabi belajar terganggu

3) Dampak sosial: lebih banyak di rumah atau menarik diri dari lingkungan sosial, merasa di cap jelek.

Secara garis besar hasil penelitian ini menunjukkan bahwa anak-anak yang berkonflik dengan hukum rentan mengalami kekerasan di berbagai tahap proses hukum yang dilaluinya. Bentuk kekerasan yang dialami dapat berupa kekerasan fisik, kekerasan verbal, kekerasan psikologis, dan kekerasan finansial. Kekerasan yang dialami oleh anak yang berkonflik dengan hukum memberikan dampak psikologis, sosial, dan fisiologis. Adapun skemanya sebagaimana gambar 1 di bawah ini:

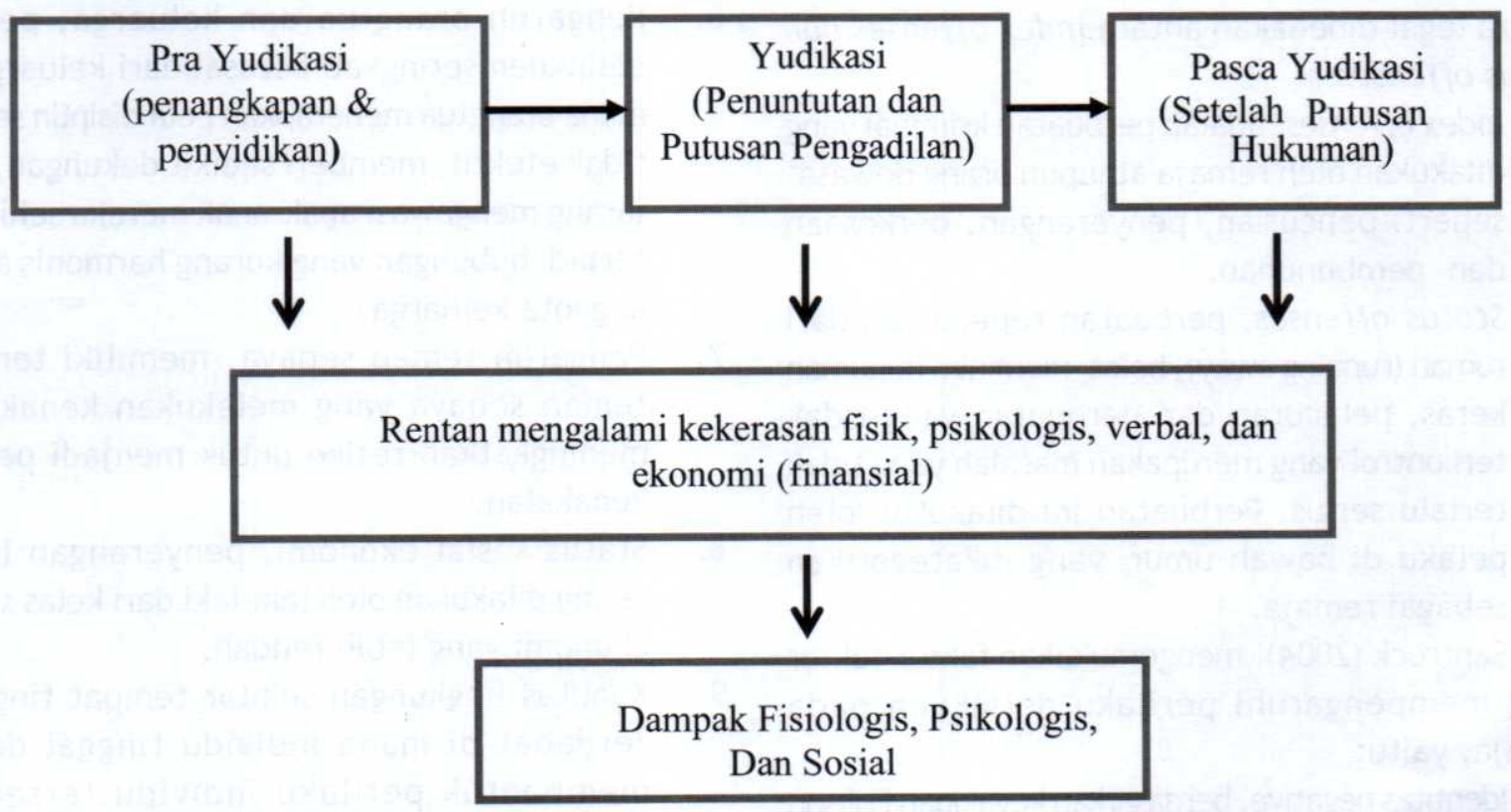

Gambar 1:

Skema Dampak Fisiologis, Psikologis dan Sosial pada Anak yang Berkonflik dengan Hukum 


\section{DISKUSI}

Anak-anak masih memiliki pemahaman yang sederhana mengenai perilaku. Mereka belum memiliki pertimbangan yang matang mengenai dampak atas perbuatan yang dilakukan. Perilaku tersebut kecenderungannya di dorong oleh rasa ingin tahu dan konformitas teman sebaya dan orang-orang disekitarnya.

Anak sebagaimana tertulis dalam Undangundang no. 23 tahun 2002 anak adalah bagian dari hak asasi manusia yang wajib dijamin, dilindungi, dan dipenuhi oleh orang tua, keluarga, masyarakat, pemerintah, dan Negara. Setiap anak selama dalam pengasuhan orang tua, wali, atau pihak lain mana pun yang bertanggung jawab atas pengasuhan, berhak mendapat perlindungan dari perlakuan (a.) diskriminasi;(b.) eksploitasi, baik ekonomi maupun seksual; (c.) penelantaran; (d.) kekejaman, kekerasan, dan penganiayaan; (e.) ketidakadilan; dan (f.) perlakuan salah lainnya.

Anak berhadapan dengan hukum disebut juga sebagai juvenile delinquency. Menurut Kartono, (2006) delinkuen mengacu pada suatu bentuk perilaku menyimpang yang merupakan hasil dari pergolakan mental serta emosi yang sangat labil. Menurut Santrock (2004) perilaku delinkuen merupakan masalah perilaku yang luas mulai dari perilaku yang tidak dapat diterima secara sosial (acting out in school), status offenses (running away), sampai pada perbuatan kriminal (pencurian). Secara legal dibedakan antara index offenses dan status offenses.

1) Index offenses, adalah perbuatan kriminal yang dilakukan oleh remaja ataupun orang dewasa, seperti pencurian, penyerangan, perkosaan dan pembunuhan.

2) Status offenses, perbuatan seperti lari dari rumah (running away), bolos, meminim minuman keras, pelacuran dan perbuatan yang tidak terkontrol yang merupakan masalah yang tidak terlalu serius. Perbuatan ini dilakukan oleh pelaku di bawah umur, yang dikategorikan sebagai remaja.

Santrock (2004), mengemukakan faktor-faktor yang mempengaruhi perilaku delinkuen pada remaja, yaitu:

1. Identitas negative, berdasarkan keyakinan Erikson (dalam Santrock, 2004) bahwa perilaku delinkuen muncul karena remaja gagal menemukan suatu identitas peran atau usaha untuk membangun identitas, walaupun identitas tersebut negatif.
2. Pengendalian diri rendah, kebanyakan remaja telah mempelajari perbedaan antara tingkah laku yang dapat diterima dan tingkah laku yang tidak dapat diterima, namun remaja yang melakukan kenakalan tidak mengenali hal ini. Para remaja tersebut gagal membedakan kedua tingkah laku tersebut.

3. Usia, Tingkah laku antisosial di usia dini (anakanak) berhubungan dengan perilaku delinkuen yang lebih serius di masa remaja. Namun, tidak semua anak bertingkah laku seperti itu nantinya akan menjadi pelaku delinkuen

4. Jenis kelamin (laki-laki). Anak laki-laki lebih banyak melakukan perilaku antisosial daripada anak perempuan. Kartono (2006), mengungkapkan perbandingan perilaku delinkuen anak lakilaki dengan perempuan diperkirakan 50:1. Berdasarkan data statistik, jumlah anak laki-laki yang melakukan kejahatan dan perilaku delinkuen lebih banyak daripada perempuan, kecuali dalam hal lari dari rumah. Anak laki-laki pada umumnya melakukan perilaku delinkuen dengan jalan kekerasan, perkelahian, penyerangan, perusakan, pengacauan, perampasan dan agresivitas.

5. Harapan dan nilai yang rendah terhadap pendidikan. Remaja pelaku delinkuen seringkali memiliki harapan yang rendah terhadap pendidikan dan juga nilai-nilai yang rendah di sekolah

6. Pengaruh orangtua dan keluarga, pelaku delinkuen seringkali berasal dari keluarga di mana orangtua menerapkan pola disiplin secara tidak efektif, memberi sedikit dukungan, dan jarang mengawasi anak-anak mereka sehingga terjadi hubungan yang kurang harmonis antar anggota keluarga

7. Pengaruh teman sebaya, memiliki temanteman sebaya yang melakukan kenakalan meningkatkan resiko untuk menjadi pelaku kenakalan.

8. Status sosial ekonomi, penyerangan lebih sering dilakukan oleh laki-laki dari kelas sosial ekonomi yang lebih rendah.

9. Kualitas lingkungan sekitar tempat tinggal. Terdapat di mana individu tinggal dapat membentuk perilaku individu tersebut, masyarakat dan lingkungan yang membentuk untuk berperilaku baik atau buruk.

Undang-undang Nomor 4 Tahun 1979 tentang Kesejahteraan Anak, mempunyai relevansi dengan children involved with the system of administration of 
juvenile justice. Dalam Pasal 6 tersebut menyatakan sebagai berikut : (1) Anak yang mengalami masalah kelakuan diberi pelayanan dan asuhan yang bertujuan menolongnya guna mengatasi hambatan yang terjadi dalam masa pertumbuhan dan perkembangannya. (2) Pelayanan dan asuhan, sebagaimana dimaksudkan dalam ayat (1), juga diberikan kepada anak yang telah dinyatakan bersalah melakukan pelanggaran hukum berdasarkan keputusan hakim.

Masalah anak-anak yang berkonflik dengan hukum juga diatur dalam Undang-Undang HAM Nomor 39 Tahun 1999 dalam Pasal 52-66, yaitu: (1) Setiap anak berhak untuk tidak dijadikan sasaran penganiayaan, penyiksaan atau penjatuhan hukuman yang tidak manusiawi. (2) Hukuman mati atau hukuman seumur hidup tidak dapat dijatuhkan untuk pelaku tindak pidana yang masih anak. (3) Setiap anak berhak untuk tidak dirampas kebebasannya secara melawan hukum. (4) Penangkapan, penahanan, atau pidana penjara anak hanya boleh dilakukan sesuai dengan hukum yang berlaku dan hanya dapat dilaksanakan sebagai upaya terakhir. (5) Setiap anak yang dirampas kebebasannya berhak mendapatkan perlakuan secara manusiawi dan dengan memperhatikan kebutuhan pengembangan pribadi sesuai dengan usianya dan harus dipisahkan dari orang dewasa, kecuali demi kepentingannya. (6) Setiap anak yang dirampas kebebasannya berhak memperoleh bantuan hukum atau bantuan lainnya secara efektif dalam setiap tahapan upaya hukum yang berlaku. (7) Setiap anak yang dirampas kebebasannya berhak untuk membela diri dan memperoleh keadilan di depan pengadilan anak yang obyektif dan tidak memihak dalam sidang yang tertutup untuk umum.

Anak-anak terkadang mengalami situasi sulit sehingga mereka harus berhadapan dengan hukum karena tindakannya. Walaupun demikian, anak yang melanggar hukum tidaklah layak untuk diperlakukan secara semena-mena, dianiaya, diperlakukan tidak adil, apalagi dimasukkan penjara. Menurut Nevid, dkk (2005) anak-anak yang dianiaya atau ditelantarkan sering mengalami kesulitan membentuk hubungan sehat dengan sebaya, dan keterikatan yang sehat dengan orang-orang lain. Mereka kekurangan kapasitas empati, atau gagal mengembangkan suara hati dan kepedulian mengenai kesejahteraan orang lain.

Menurut Suyanto (2010) jenis kekerasan psikis yang dialami tidak begitu mudah dikenali. Akibat yang dirasakan korban tidak memberikan bekas yang nampak jelas bagi orang lain. Dampak kekerasan jenis ini akan berpengaruh pada situasi perasaan tidak aman dan nyaman, menurunkannya haraga diri serta martabat korban. Wujud konkrit kekerasan jenis ini adalah: penggunaan kata-kata kasar, penyalahgunaan kepercayaan, mempermalukan orang lain di depan umum, melontarkan ancaman dengan kata-kata dan sebagainya. Akibat adanya perilaku tersebut biasanya korban akan merasa rendah diri, minder, merasa tidak berharga, dan lemah dalam membuat keputusan.

Efek-efek psikologis lain yang umum dari penelantaran dan penganiayaan mencakup menurunnya harga diri, depresi, perilaku tidak matang, seperti mengompol, mengisap jempol, upaya-upaya lain dan pikiran bunuh diri, kinerja buruk di sekolah, masalah-masalah perilaku dan kegagalan mengambil resiko, menjelajah keluar rumah untuk mengeksplorasi dunia luar (Nevid, kk, 2005). Situasi-situasi yang dihadapi $A B H$ merupakan situasi yang sangat sulit untuk anak karena mereka berada pada tahap-tahap perkembangan yang harus dilalui dengan perhatian, bimbingan, dan dukungan dari orang-orang dewasa disekitarnya (orang tua, guru, dan lain sebagainya), serta perlindungan hukum dari negara.

\section{PENUTUP}

\section{Kesimpulan dan Implikasi}

Adapun kesimpulan mengenai penelitian ini adalah :

1. Anak yang berkonflik dengan hukum memiliki kerentanan mengalami kekerasan pada tahaptahap proses hukum yang dilalui, yaitu tahap pra yudikasi, yudikasi, dan pasca yudikasi

2. Bentuk kekerasan yang rentan dialami oleh anak yang berkonflik dengan hukum adalah kekerasan fisik, kekerasan psikologis, kekerasan verbal, dan kekerasan ekonomi (finansial)

3. Kekerasan yang dialami oleh anak yang berkonflik dengan hukum memberikan dampak, baik secara fisiologis, psikologis, maupun sosial.

Saran

Hasil penelitian ini diharapkan dapat menjadi referensi bagi aparat penegak hukum dan masyarakat untuk melakukan kontrol terhadap proses hukum yang dijalani oleh anak-anak. Apapun alasannya, anak-anak tidak berhak diperlakukan secara tidak adil, diperlakukan semena-mena, atau dijadikan korban kekerasan. Selain itu, hasil penelitian ini juga diharapkan sebagai pijakan untuk memperlakukan anak yang berkonflik secara hukum lebih manusiawi sesuai dengan tahap perkembangan anak. Hukum yang peka terhadap hak dan kebutuhan anak. 
Secara teoritik hasil penelitian ini diharapakan mampu memberikan kontribusi pada khasanah ilmu pengetahuan khususnya ilmu psikologi dan ilmu hukum. Peneliti selanjutnya juga dapat melengkapi

\section{DAFTAR PUSTAKA}

Bagong .S, dkk. (2000). Tindak Kekerasan Mengintai Anak-anak Jatim. Surabaya : Lutfansah Mediatama.

Bagong Suyanto, (2010)., Masalah Sosial Anak, Jakarta: Kencana.

Hadisuprapto, Paulus, (2002), Pemberian Malu Reintegratif sebagai Sarana Nonpenal Penanggulangan Perilaku Delinkuensi Anak (Studi Kasus di Semarang dan Surakarta), Disertasi, Program Doktor Ilmu Hukum Universitas Diponegoro, Semarang.

Hadisuprapto, Paulus, (2008), Delikuensi Anak:Pemahaman dan Penanggulangannya, Malang:Bayumedia.

Harahap, yahya., (2006)., Pembahasan Permasalahan Dan Penerapan KUHAP, Penyelidikan Dan Penuntutan., Edisi kedua., Jakarta: Sinar Grafika

Huraerah, Abu., (2006), Child Abuse, Kekerasan Terhadap Anak, Bandung; Penerbit Nuansa.

Huraerah, Abu., (2007), Child Abuse, Kekerasan Terhadap Anak, Edisi Revisi, Bandung; Penerbit Nuansa. kelemahan-kelemahan yang ada dalam penelitian ini, misalnya mengekplorasi lebih luas mengenai aspek-aspek yang terkait anak yang berkonflik dengan hukum.

Kartini, Kartono. (2006). Psikologi Abnormal dan Abnormalitas Seksual. Bandung: CV Mandar Maju.

Listyawati Andayani., (2010)., Kasus kekerasan anak yang berkonflik dengan hukum., Jurnal PKS Vol.IX, No.31, Maret 2010; hal 103 - 111

Monks, dkk, (2015), Psikologi Perkembangan: Pengantar Dalam Berbagai Bagiannya, Gadjah Mada Univesity Press.

Nashriana., (2011)., Perlindungan Hukum Pidana Bagi Anak di Indonesia, Jakarta: Raja Grafindo Persada.

Nevid, dkk., (2005)., Psikologi Abnormal., Penerbit Erlangga Jakarta.

Patricia, A Potter., \& Anne Griffin Perry., (2001)., Buku Ajar Fundamental keperawatan: Konsep, Proses, dan Praktik., Edisi 4, Volume II., Jakarta; EGC).

Santrock, John W ., (2004)., Perkembangan Remaja., Penerbit : Erlangga.

Yin K. Robert, Prof. (2011). Studi Kasus; Desain dan Metode. PT. RajaGrafindo Persada. Jakarta. 